Meta

Journal des traducteurs

Translators' Journal

\title{
Redefining Translation Competence in an Electronic Age. In Defence of a Minimalist Approach
}

\section{Anthony Pym}

Volume 48, numéro 4, décembre 2003

URI : https://id.erudit.org/iderudit/008533ar

DOI : https://doi.org/10.7202/008533ar

Aller au sommaire du numéro

Éditeur(s)

Les Presses de l'Université de Montréal

ISSN

0026-0452 (imprimé)

1492-1421 (numérique)

Découvrir la revue

Citer cet article

Pym, A. (2003). Redefining Translation Competence in an Electronic Age. In Defence of a Minimalist Approach. Meta, 48(4), 481-497.

https://doi.org/10.7202/008533ar
Résumé de l'article

La compétence traductionnelle a été conceptualisée comme étant 1) une modalité du bilinguisme, donc sujet à l'analyse linguistique, 2) un effet des demandes du marché, donc sujet à un fort relativisme historique et social, 3) une compétence pluricomponentielle, donc sujet à une approche interdisciplinaire à la fois linguistique, culturelle, technologique et professionnelle, et 4) une vague « hypercompétence » qui en quelque sorte transcenderait tout le reste. La tendance générale depuis les années 1970 a été d'élargir le modèle pluricomponentiel en sorte que l'on ajoute constamment des habiletés nouvelles au champ de la formation des traducteurs. Cette tendance a toutes les chances de se répandre encore, grâce en premier lieu à l'emploi croissant des outils électroniques. On est en droit de se demander, pourtant, si les élargissements du modèle pluricomponentiel ne répondent pas en partie aux intérêts propres aux institutions qui prétendent former les traducteurs. D'ailleurs, un tel modèle serait à jamais en quête d'un marché qui s'élargit plus vite que lui. Plus satisfaisant nous semble une conceptualisation minimaliste de la compétence traductionnelle, basée celle-ci sur la production puis triage des variantes. Grâce à sa simplicité même, ce genre de compétence pourrait nous aider à orienter la formation des traducteurs, malgré toutes les turbulences technologiques et professionnelles.
Ce document est protégé par la loi sur le droit d'auteur. L'utilisation des services d'Érudit (y compris la reproduction) est assujettie à sa politique d'utilisation que vous pouvez consulter en ligne.

https://apropos.erudit.org/fr/usagers/politique-dutilisation/ 


\title{
Redefining Translation Competence in an Electronic Age. In Defence of a Minimalist Approach*
}

\author{
ANTHONY PYM \\ Universitat Rovira i Virgili, Tarragona, Spain \\ ap@fll.urv.es
}

\begin{abstract}
RÉSUMÉ
La compétence traductionnelle a été conceptualisée comme étant 1) une modalité du bilinguisme, donc sujet à l'analyse linguistique, 2) un effet des demandes du marché, donc sujet à un fort relativisme historique et social, 3) une compétence pluricomponentielle, donc sujet à une approche interdisciplinaire à la fois linguistique, culturelle, technologique et professionnelle, et 4) une vague «hypercompétence» qui en quelque sorte transcenderait tout le reste. La tendance générale depuis les années 1970 a été d'élargir le modèle pluricomponentiel en sorte que l'on ajoute constamment des habiletés nouvelles au champ de la formation des traducteurs. Cette tendance a toutes les chances de se répandre encore, grâce en premier lieu à l'emploi croissant des outils électroniques. On est en droit de se demander, pourtant, si les élargissements du modèle pluricomponentiel ne répondent pas en partie aux intérêts propres aux institutions qui prétendent former les traducteurs. D'ailleurs, un tel modèle serait à jamais en quête d'un marché qui s'élargit plus vite que lui. Plus satisfaisant nous semble une conceptualisation minimaliste de la compétence traductionnelle, basée celle-ci sur la production puis triage des variantes. Grâce à sa simplicité même, ce genre de compétence pourrait nous aider à orienter la formation des traducteurs, malgré toutes les turbulences technologiques et professionnelles.
\end{abstract}

\begin{abstract}
Since the 1970 s the notion of "translation competence" has been viewed as at least 1 ) a mode of bilingualism, open to linguistic analysis, 2) a question of market demands, given to extreme historical and social change, 3) a multicomponent competence, involving sets of skills that are linguistic, cultural, technological and professional, and 4) a "supercompetence" that would somehow stand above the rest. The general trend among theorists has been to expand the multicomponent model so as to bring new skills and proficiencies into the field of translator training. This trend may be expected to continue with the increasing use of electronic tools. Here it is argued, however, that the multicomponential expansions of competence are partly grounded in institutional interests and are conceptually flawed in that they will always be one or two steps behind market demands. On the other hand, a simple minimalist concept of translation competence, based on the production then elimination of alternatives, can help orient translator training in times of rapid technological and professional change.
\end{abstract}

\section{MOTS-CLÉS/KEYWORDS}

translation competence, translator training, translation process, translation skills

My students are complaining, again. In our Advanced Translation course we are not really translating, they say. But, I quickly reply, we have learned how to use Revision tools and Comments in Word; we have discovered a few good tricks for Internet 
searches; we have found out about HTML; we can create and localize fairly sophisticated websites; we can do wonderful things with translation memories... and these are the things that the labour market is actively looking for. All that, I insist, is part and parcel of translating these days. No, some still reply, what we want is lists of false friends, modulation strategies, all the linguistic tricks, plus some practice on a few really specialized texts... and that, my more critical students believe, is the invariable hard core of what they should be learning in the translation class.

How should that conflict be resolved? A practical proposal will be given somewhere near the end of this paper. More interesting, though, is the general theoretical and pedagogical problem involved. Those students and I have a fundamental disagreement about what translating is and how it should be taught. We disagree about the nature of translation competence. As a teacher, I want to convey the whole range of skills required by the labour market. And yet, I admit, my critical students have a point: when they sign up for translation, they should expect to translate, on the basic level of an interface between languages, the stuff of linguistics. So is translation competence really the same as it always was (as those students expect)? Or has it radically altered in the age of electronic tools (as the nature of my course would suggest)?

\section{Four notions of translation competence}

What is translation competence? So as not to reinvent the wheel, we begin from a few pages written by the German scholar Wolfram Wilss in 1976, somewhere near the beginning of institutionalized Translation Studies. Wilss says four quite different things about translation competence.

First, he notes rather depressingly, his infant Applied Science of Translation

cannot provide a satisfactory answer to the question of the professional minimum qualification of a translator, above all, because translational competence as a uniform qualification for translational work is, to all intents and purposes, nonexistent and probably also nondefinable. (1976: 119)

So "competence" cannot be confused with questions of professional qualifications, no matter how much teachers like myself might worry about training students for the workplace. This makes sense, since qualifications change with technology and social demands, bringing in bundles of history that are simply too big for the eternal generalities of a science. Then again, if the science is supposed to help train translators, and translators are going to be employed for whatever competence they acquire, surely we cannot just remain silent about what the market requires?

Wilss's second point then stands in stark contrast with the first. Now, apparently, the translator needs eight "competence ranges," each with two subcategories (for the two languages involved), giving a grand total of sixteen compartments for all the things that trainees should learn to do with language. Why sixteen? Why not 127 ? Or just seven? No reason is given for the selection of the categories, which have no more weight than their origins in very basic linguistics. Yet the "multicomponent" idea was thus announced, and it could potentially be expanded and contracted at will.

The third idea would then seem to restrict this expansion: Wilss notes that "[b]oth subcompetences [those of the two languages concerned] are in complementary relation with each other and together constitute the basis of translational competence" 
(120). This is rather like saying $1+1=2$, where translational competence is the summation of what the translator knows in two languages. This does at least make the numbers neater.

However, as if things had not become confusing enough, Wilss's fourth and final point would seem to say something quite different. Now translation competence is "clearly marked off from the four traditional monolingual skills: listening, speaking, reading, and writing," thus becoming something like a "supercompetence" (120).

So we find in the early Wilss a claim that there is no such thing as translation competence, then a multicomponent definition of it, a two-language-summation model, and final mention of a mysterious metacompetence, all in the space of two pages! Which of those ideas was to win the day?

Here we shall briefly outline the adventures and avatars of those ideas since the 1970s. Our history should then explain the reasons behind our own proposed definition.

\section{Competence as a summation of linguistic competencies}

Let us begin with the $1+1$ idea, which seems to make intuitive sense. In his The Science of Translation (1982) Wilss more or less stuck with this language-summation concept: the translator "must have an SL [source-language] text-analytical competence and a corresponding TL [target-language] text-reproductive competence" (118). Translators are people who are competent in two languages, and their work clearly involves putting those two competencies together. This is more or less what we find in Brian Harris's early positioning of translation competence as something that bilingual children develop as they carry out "natural translation" (Harris 1977; Harris and Sherwood 1978). Bilinguals would start translating for themselves, then for others, and this progression should hold some keys for what all translators do. The linguistics of bilingualism might thus also become the linguistics of translation, and no separate academic discipline need develop. In much the same vein, Werner Koller described translation competence as being "the ability to put together [verbinden] the linguistic competencies gained in two languages" (1979: 40). ${ }^{1}$ Michel Ballard contended that the secrets of teaching translation lay in the "use of two languages at the same time" (1984: 17), once again assuming that the level of the translator's practice is basically a summation of tongues. This kind of competence would seem an abstract version of bilingualism, roughly in tune with Harris's mode of thought.

All these descriptions look obvious enough. However, for anyone seeking institutional independence, a separate place to train translators and to think about translation, simple summation was not a happy mode of thought. It kept Translation Studies within Applied Linguistics, and Translator Training within language schools or Modern Language departments. The dominant trend in academic politics, at least in the 1970s and 1980s (the dates of our citations), was to seek greater power by becoming independent. Very few voices argued against that idealized independence. The summation idea was consequently short-lived as such, although its underlying naturalism (Harris's "natural translation") would also inform later models drawing on cognitive linguistics. 


\section{Competence as no such thing}

Why did Wilss not want to deal with competence as a "professional minimum qualification"? One reason certainly lies in the nature of the eternal science he was trying to build. Another surely stems from the fact that the term "competence" denoted a key concept in linguistics, which was perhaps the dominant discipline in the humanities of the day. That concept was as far from historical markets as could be imagined. Chomsky had distinguished between "competence" and "performance," which could be mapped very loosely onto Saussure's distinction between langue and parole. So the term "translation competence" should have referred to a kind of systemic knowledge underlying the actual performances of translators, in the same way a grammar underlies the use of speech. The early Koller (1979: 185) nevertheless held translation competence to be qualitatively different from linguistic competence in the same way that speech (parole) is different from tongue (langue), which would in fact put translation competence on the "performance" side of the Chomskyan divide. That is, this particular kind of competence concerned the actual use of language, no matter how firmly Chomskyan linguistics had anchored the term "competence" on the other side of its divides. This was Koller's strategy for separating Translation Studies from Contrastive Linguistics, and thus gaining institutional space. Unfortunately, Saussure (1974: 19ff.) had argued that nothing scientific could be said about parole at all, and Chomsky (1965) had removed translation entirely from the scope of his ambitions. To argue that there was a competence within performance, or system within parole, was to embark on paradoxes that hard-core linguistic science simply did not want to entertain.

How could the paradox of a performance-based competence be resolved? In the early days, it meant following non-Chomskyan linguistics, which usually involved the adoption of alternative terms. By 1988 Wilss was doing psycholinguistics, appealing to a cognitive approach in which translation competence was a summation of declarative knowledge and "knowledge of translation processes" (übersetzungsprozessuale Wissen), although the nature of the latter was still far from clear. In 1989 we find Wilss using the alternative vocabulary of "skills" (Fertigkeiten); in 1992 he was ready to abandon "competence" altogether and replace it with the more pedagogical term "proficiency" (1992: 185). Lörscher, writing in terms of psycholinguistics in 1991, similarly claimed not to need "competence" at all; he somehow thought the concept was not concerned with actual translation processes (1991:2), which meant he could happily get by with talk of "strategies" being used to solve problems. Nor was there any particular terminological problem when an even more mature Wilss (1996: 4) referred to sociolinguistics to describe the use of languages as "code-sharing," such that translation becomes a case of "code-switching" (a valuable insight that seems not to have been picked up anyone else). Shreve (1997: 130) draws on cognitive linguistics, describing language competencies as "mapping abilities," thus allowing translation competence to become the process by which a translator can "map mappings." Risku (1998) names her object as "translatorial competence" but then immediately switches to the discourse of "expertise," established as a key term since the mid-1980s (cf. Holz-Mänttäri 1984). Schäffner and Adab (2000: x) explicitly accept that "competence" involves any number of other terms; they actually propose that it be accepted as "a cover term and summative concept for the overall performance 
ability which seems so difficult to define" (ibid.). But note the almost unthinking reduction to "performance ability," as if there had never been a paradox to resolve. In fact, in most of these authors, including those brought together in the volume on Developing Translation Competence edited by Schäffner and Adab (2000), we find the term "competence" simply being kicked around the park, with the more substantial referent then becoming something else, some other term.

So would the problems of translation competence be solved simply by not using the word? Yes and no. In the early years it made sense to seek alternative words, if only to avoid the strictures of Chomsky. However, the abandonment of "competence" ultimately proved to be unnecessary. The very nature of linguistics had been changing even more, with increasing attention to discourse analysis, text linguistics, pragmatics, psycholinguistics and sociolinguistics, all of which similarly required a positioning of "competence" somewhere near the performance side. The moves made by translation theorists were mostly in step with the trends of linguistics itself, albeit with a much more restricted level of theoretical awareness.

\section{Competence as multicomponential}

Parallel to this search for other words, the multicomponent idea was accumulating quite a rich history, much of it drawing on research in second-language acquisition and similarly benefiting from the many "performance-level" trends in linguistics. Bell (1991) describes translator competence as a huge summation: target-language knowledge, text-type knowledge, source-language knowledge, subject area ("realworld") knowledge, contrastive knowledge, then decoding and encoding skills summarized as "communicative competence" (covering grammar, sociolinguistics and discourse). Virtually everything that any kind of linguistics wanted to talk about was tossed into the soup. Christiane Nord (1991: 165-166), drawing on Bausch (1977), actually distinguishes between the kind of competence needed by translators and the competence that translation practice could develop in the language class (awareness of contrastive structures, and skills like the effective use of dictionaries), but she nevertheless refuses to exclude any of those aspects from her pedagogical model. This general approach could give some relatively simple formulations. For instance, Neubert (1994: 412) offers "language competence," "subject competence" and "transfer competence" as the three main components. Lee-Jahnke reduces the translator's "objective knowledge" to three different heads: mother tongue, foreign tongue and "sociocultural background" (1997: 178). And yet once one drives into third terms like these, various labyrinths are opened and there is virtually no limit to the number of things that may be required of a translator. Hatim and Mason (1997: 204-206), working from Bachman (1990), present a traditional three-part competence inherited from linguistics (ST processing, transfer, TT processing) and then name a handful of skills for each of those heads. Hewson (1995) adds something called "cultural and professional elements" (108), where the "professional" part refers to "remuneration [...] access to and use of proper dictionaries and data banks, access to equivalent material in the second language, practical knowledge of word-processors and peripherals, and so on" (ibid.). Hurtado (1996) breaks down translation competence into linguistic, extralinguistic, textual (comprehension and production), general "professional skills," and "transfer competence" (competencia translatoria, later called 
competencia de transferencia), described in a Harris-like way as "a predisposition to change from one language to another without interferences” (1996: 34). In 1999 (43$44,245-246)$ we find the same author adding things called "strategic competence" (since strategies had become fashionable) and "psychophysiological competence" (no doubt to make sure all the bases are covered). Presas (1997) allows for languagebased core competencies (ST reception, production of a draft TT, production of a final TT) and then adds a series of "peripheral competencies" that include the use of dictionaries, documentation, area knowledge, uses of briefs, and technological tools. In a later text (1998), the same author adds "adequate memory configuration," "flexibility of code-switching" and "interference control" as components of a specifically "pretranslation" competence. This in fact allows for certain modes of language teaching to become parts of translator training, redefining key institutional boundaries (cf. Mayoral 2001: 125). Beeby $(1996,2000)$ follows a similar tendency to multiplication, detailing six sub-competencies all churning within the one translation competence, each of them with up to four or five sub-components. Kautz (2000: 20) takes a slightly different approach, recognizing that translators need knowledge of two languages, world and field knowledge, translation theories and methods, and then something else called "translatorial competence" (translatorische Kompetenz) that covers skills in the analysis of the client's brief and the ST, translation strategies, TT presentation (including layout), documentation, terminology, and knowledge of the translator's professional practice. What is truly remarkable here is how long it took definitions of competence to include reference to the client's brief (Auftrag, "instructions," "commission"), a key point in German-language Skopostheorie since 1984. In Fraser (2000) we find further development of this line, where freelance translators describe their competence in terms of "a detailed briefing and resources for the job in hand, coupled with feedback and evaluation of the finished translation in terms of how well it fulfils its purpose or meets its readers' needs" (60), all of which sound more like simple desiderata than any strict kind of competence. Mayoral (2001: 109) insists on components including "common sense (above all), curiosity, ability to communicate, capacity for self-criticism, meticulousness, ability to synthesize, etc.” Anything else? In Douglas Robinson's Becoming a Translator (1997) we find serious attention to the real-world necessities of good typing speeds, Internet discussion groups, and working with a computer in a room at the right temperature (sic). For that matter, Pym (1992) has pointed out the strategic benefits of wearing a good suit and tie, especially on days when you have a hangover. And the ever-present Wilss (1996: 11), with the irony of the wise, recognizes that timeliness is an essential requisite of translators ("fast is smart"), along with the similarly efficient "reduction of complexity," all of which could lead anywhere.

Why was the time factor not mentioned in any of Wilss's earlier formulations? Indeed, why were these many necessary things absent from almost all the initial definitions? And why should the lists of components seem to have grown larger over the years? Perhaps because the earlier scholars were thinking in terms of linguistics and students, and not in terms of how translators work in the world (such was the exclusion explicit in Wilss). Maybe because scholars simply like talking about a lot of things. Or are they just intellectually inept, given to producing falsely authoritative lists? Perhaps, also, the explosion of components has followed the evolution of Translation Studies as an "interdiscipline," no longer constrained by any form of hard-core 
linguistics. Since any number of neighbouring disciplines can be drawn on, any number of things can be included under the label of "translation competence." At the same time, even more importantly, the evolution of the translation profession itself has radically fragmented the range of activities involved. In the 1970s, translators basically translated. In our own age, translators are called upon to do much more: documentation, terminology, rewriting, and the gamut of activities associated with the localization industry. That is why our class, at the beginning of this paper, was focused on electronic tools. Perhaps, at base, the explosion of components has merely followed the profession into a more fully electronic age. The difficulty that Wilss had intimated back in 1976 (that market requirements in this field are too historical to be systematized as a competence) has been evidenced in history itself: the more scholars look, the more things they put in, with no limit in sight.

The methodological shortcomings of the multicomponent models are fairly obvious. Waddington (2000: 135) lists three: 1) it is hard to know how many components should be a part of translation competence, 2) the definitions tend to concern ideal competence, and are thus incomplete without a model of the learning process (cf. Toury 1995: 238), and 3) there is a dearth of empirical evidence for most of the available models. While agreeing with the first two complaints, we would not necessarily go along with the third. ${ }^{2}$ And we might add a fourth broad complaint: Innocently descriptive as they seem, the multicomponent models of competence are heavy with assumptions not just about what translation is and how it should be taught, but more especially about the level at which specific teaching is needed, and for how many years. They inevitably feed into complex professional profiles ("a good translator needs A, B and C..."); they thus underscore not just a transcendental ideal translator who has no place in the fragmented market, but also the long-duration interdisciplinary training programs that purport to produce such things (mostly university degree programs lasting four or five years). In most cases, the complex models of competence coincide more or less with the things taught in the institutions where the theorists work. What a surprise!

Multicomponentiality has undoubtedly followed the fragmentary development of the profession; it is obviously a response to interdisciplinarity and the break with linguistics; but institutionally it operates as a political defence of a certain model of translator training. And that model is not the only one, nor necessarily the best.

\section{Competence as just one thing}

Wilss, it will be remembered, also suggested that translation competence was a kind of "supercompetence," over and above the various linguistic components. That rather vague notion was developed in later minimalist definitions. Gideon Toury $(1984,1986)$, at that time engaged in polemics with Harris over the nature of "natural translation," was going in the same direction when he hypothesized a specific "transfer competence" that was not a simple overlap of competencies in two languages: it required particular modes of socialization (cf. Toury 1995: 246, 250). But what was the exact nature of this necessary third term? Hans P. Krings (1986) produced a typology of translation problems in which some concerned ST comprehension, others had to do with target-language skills, and a third group involved strictly interlingual questions. This third group was then labeled "translation competence" 
problems (112-171), also described as "reception-production problems" (144-152). Similarly, when Werner Koller restated his position on translation competence in 1992, he stressed that it was "not simply more language competence [...] but also the creativity involved in finding and selecting between equivalents, and in the increasingly necessary [skills of] text production" (1992: 20). Shreve could be saying the same thing when he talks about the need to "map mappings" (1997: 130). And we have seen similar ideas occurring at various places within the multicomponent definitions, although the plurality of other components has tended to hide whatever specificity might belong to this one. The various words for the third (or fourth, or fifth!) term might have been naming the same thing, the singular specificity of translation. Yet there has been no visible consensus on the point.

Given the inherent failure of the multicomponent models to keep up with historical change, serious thought should now be invested in the minimalist "supercompetence" approach. This means accepting that there is no neat definition of all the things that translators need to know and will be called upon to do. Nor is there any reason to suppose that competence is at all systematic, like the grammatical and phonological rules that once provided the term with its archetypal content. What we need, beyond lists and systems, is a concept that might define translating and nothing but translating. Only then could we orient the rest.

Can empirical studies help with this problem? It is difficult to imagine what kind of research design could determine the specificity of translating. Empiricism could mean simply asking different people what they think translation competence should be, but that would give no guarantee that the various groups use the key terms ("translation" and "competence") in anything like the same way (cf. Fraser 2000). Whether we like it or not, the terms have to be defined first.

For an example of possible empiricism, let us briefly consider the early research mentioned above. Krings (1986) studied six translations by German students working into French (their first foreign language, or L2). The problems they encountered were then categorized as having to do with either their knowledge of French or with interlingual processes, the latter then being described as concerning "translation competence," which would seem to be what we are looking for here. However, it was found that only $6.5 \%$ of the problems actually fell into this latter category (they were classified as such when L2 factors seemed not to be involved). In his critique of this research, Löscher (1991: 96) correctly points out that the small percentage is not only hard to distinguish from the rest, but that the distinction itself had no psychological reality for the subjects, since there was no evidence that the students thought about these problems in markedly different ways. One can only conclude that Krings brought the categories to bear on the data, rather than derive his model of translation competence bottom-up from the data itself. And this, we suggest, is necessarily so.

More engaging would seem the work by Campbell (1992) on 41 students' translations of the same text from L2 Arabic. Campbell considers translation competence to have two quite different components: "disposition," covering psychological qualities such as risk-taking and persistency, and "proficiency," which includes "certain bilingual skills and has a developmental dimension." This is of interest because the "disposition" part would account for why different translators work in different ways (cf. the "creativity" mentioned by Koller in 1992), whereas "proficiency" would seem to refer to a more static kind of knowledge (lexical coding, global TL competence, 
and content/function words). Once again, it is hard to believe that the data would have given those categories had the researcher not set out to combine psycholinguistics with studies on bilingualism. The disciplinary position was there prior to the research. Yet here, under the very vague head "disposition," we do seem to be approaching something rather more concrete that could belong to translating and nothing but translating.

Can empirical research be of help? Undoubtedly yes. Our models and definition must be able to make sense of reams of data on many levels (translations, errors, doubts, expectations, time constraints, whatever), and should ideally do so in a way that makes the models and definitions falsifiable (this aspect has been sadly missing). Then again, no, the key step resides in the intellectual task of staking out the field of study in the first place. And there, in the production of a definition, the problem is not just to account for data; it is also to approach some kind of consensus among the translation community, it should orient research, and it should ideally focus training. In all of this, a definition can look as scientific as you like, but it can never really remain neutral. As we shall now see.

\section{A minimalist definition}

As an interpersonal activity working on texts (of whatever length or fragmentary status), the training of translators involves the creation of the following two-fold functional competence (cf. Pym 1991):

- The ability to generate a series of more than one viable target text $\left(\mathrm{TT}_{\mathrm{I}}, \mathrm{TT}_{2} \ldots \mathrm{TT}_{\mathrm{n}}\right)$ for a pertinent source text (ST);

- The ability to select only one viable TT from this series, quickly and with justified confidence.

We propose that, together, these two skills form a specifically translational competence; their union concerns translation and nothing but translation. There can be no doubt that translators need to know a fair amount of grammar, rhetoric, terminology, computer skills, Internet savvy, world knowledge, teamwork cooperation, strategies for getting paid correctly, and the rest, but the specifically translational part of their practice is strictly neither linguistic nor solely commercial. It is a process of generation and selection, a problem-solving process that often occurs with apparent automatism.

As an example of how this problem-solving might occur, consider the following sentence, from a text that my class was collectively rendering into English:

Los alumnos que hayan estudiado en el extranjero y deseen iniciar estudios en las universidades españolas deberán convalidar u homologar sus estudios.

This ran well enough as

Students who have studied outside Spain and wish to enter a program at a Spanish university must convalidar or homologar their foreign studies.

There was no major translation problem until we ran up against the verbs in bold. What were the trainees supposed to do? First some generated fleeting possibilities using the simplest of principles: convalidate, perhaps, but does homologate exist in English? After a few seconds of Internet searching they had located parallel texts 
giving accreditation as a general term for what is going on here. A few more seconds and they had descriptions of how the specific terms homologación and convalidación are used in bureaucratic processes (basically, the former is for degrees and diplomas as bits of paper, the latter is for the actual courses studied). But how were the translators to make the one English term cover the space of the two processes? They had few ideas; that was about as far as the generative side of business (impeccably technologized) could take them. And nothing coherent emerged until a few reductive strategies were taken into consideration. After a few leading questions about the nature and purpose of the text in question, the trainees started to consider the position of the future readers of that text, the foreign students. What might those readers require? If they did not need accreditation, then the two Spanish terms would be superfluous and could be combined into a simple accreditation. And if the readers did indeed need accreditation, they would also need those terms in Spanish, along with exact descriptions of the processes involved. So the source-text information had to be either reduced or increased, without any real need to match the two Spanish terms with two English terms. That kind of reductive reasoning, impeccably pragmatic, is perhaps the hardest part of translation competence to convey.

Our definition could be applied to many levels and strategies beyond this example, as one might expect of a "supercompetence." Its relative virtues include applicability to both intralingual and interlingual translation, recognition that there is no fixed knowledge in this field, and avoidance of any notion of meaning transfer (translating is a question of solving problems, not of moving meanings). The kind of processes we are interested in are clearly as much social as they are cognitive (the above students were discussing the translation problem as a group). The definition should thus allow for hypotheses on both levels, without assuming any kind of "natural translation" of the kind that once underwrote the language-summation model. Further, the definition refuses any notion of immutable correctness, since the criteria of viability, speed and confidence by no means rule out disagreement between translators or future improvements by the one translator. In this, we owe much to Quine's rationalist indeterminism, particularly the critique of absolute equivalence explained in terms of the common situation in which "one translator would reject the other's translation"... and both can be correct (Quine 1975: 296-297). "Viability" may in this sense involve translating for a particular readership, or to attain one of several possible purposes (the one text can be translated in many different ways). Our definition moreover allows for a degree of direct theorization within translation practice, since the generation of alternative TTs necessarily depends on a series of hypotheses formulated at some level (no matter how unaware we may be of them in many cases). From this perspective, the ability to theorize is an important part of translation competence, even if this theorization never becomes explicit. Our definition hopes to say quite a lot in very few words. It should be able to cover the most interesting parts of the many things that have been added in the multcomponent models we have seen above.

The definition nevertheless remains wilfully minimalist; its real virtue lies in the large number of things that it does not say. On a strict reading, this kind of translation competence would not concern cases where one-to-one equivalence is considered necessary or obligatory. Consider, for example, a model that takes the ST faire un discours and can only generate the one TT make a speech (the example is from 
Newmark 1985). That model might have a lot to say about terminology, language teaching or the workings of the mind in some forms of "natural translation," but it would not have a great deal to do with the specific translation competence designated by our definition (we require the generation of more than one rendition). The translation competence that interests us is thus a process of choosing between viable alternatives. And this can potentially be distinguished from mainstream terminology, language learning and naturalistic cognitive science, to name but a few of our disciplinary neighbours. To that extent, of course, the definition also has certain political virtues. It maps out an institutional area for the things we should be teaching.

\section{A defence of minimalism}

Our definition thus has the virtue of its limitations. It does not say that there is any ideal professional profile; it does not assume that no other major competencies will ever mix with this one. On the contrary, we would be more than comfortable with the assumption that such mixes are increasingly the norm, and that translation competence may often be a minor component in the range of skills required of intercultural professionals. As Gouadec puts it, "translators require a multicompetence because they must also work as documentalists, terminologists, writers, etc., BUT it is time we recognized the professional distinctions of these activities" (1991: 543). Here we are proposing a basis for precisely such a recognition. This is also somewhat akin to what Don Kiraly says when he distinguishes "translation competence" (the ability to produce an acceptable text, as above) from the wider spheres of "translator competence," which

involves joining a number of new communities such as the group of educated users of several languages, those conversant in specialized technical fields, and proficient users of traditional tools and new technologies for professional interlingual communication purposes. (2000: 13)

The profession requires such movements to and from intercultural and technical communities; it requires a plethora of new names for the new jobs thus created ("language-service provider" is currently the most apt). Yet our focus here is first and foremost on what translators bring to those communities, on their particular kind of competence. We thus stay with the term "translation competence," and with our minimalist approach.

When our definition was first presented to society, at a conference in Belgrade in 1989 (Pym 1991), it was followed by comments on three aspects of translator training: the relation between translation and language learning, the role of theory in the training of translators, and the relation between instructors and students of translation. It was hoped that a minimalist definition might have consequences for at least those three aspects, if not more. Now, some 13 years later, one must admit that the historical tendency has been well and truly away from the kind of definition we sought. It thus seems more apposite to reconsider those points now in view of how the multicomponent models have dealt with them. 


\section{The discontinuity with language learning}

A minimalist approach should ideally enable a clearer distinction between translator training and language learning. The latter should be at least to some extent analytical, rule-bound and grammar-oriented, whereas the training of translators should be relatively non-analytical, context-bound, and example-oriented. This kind of thinking was very much in tune with the institutional politics of the 1980s and early 1990s, when many translation schools, at least in Europe, were struggling to mark out their territory with respect to the established departments of Modern Languages. Mary Snell-Hornby, for example, was urging translation schools in Eastern Europe to "cut the umbilical cord" with the Modern Language departments (1994: 433). There were very few dissenting voices, although Juliane House (1986: 182) did bravely insist that acquiring communicative competence was the aim of both the language class and the teaching of translation.

Now, once that battle was won (in Spain, in 1991), many of the independent translation schools then had to fill up their four- or five-year programs. As we have seen, those institutions had a direct interest in multicomponentiality. Suddenly there was no pressing need to separate translation from bilingualism, for example, just as there was little interest in the idea of separate professional communities. It could all be brought under the one roof; it would all be part of "translation competence." In this sense strategic importance should be placed on attempts to define the special ways in which not only translation should be taught, but also the way languages should be taught for translators (cf. the "pre-translation competence" outlined in Presas 1998). The discontinuity that was once sought by virtually all translation scholars has now become a rather thin and very debatable line.

\section{The role of theory}

The minimalist approach basically sees translating as a process of producing and selecting between hypotheses, and this is in itself a mode of constant theorization. If thought through, the model is actually claiming that translators are theorizing whenever they translate; theorization is an important part of translation practice. The model also implies that whole translation approaches may be related to translating in two ways: they may help translators produce more alternatives than they would otherwise have thought of (pointing out the existence of a problem is often the most important task of theorization), and/or they may help them eliminate possible alternatives. Theories would thus be productive and/or reductive, and both kinds are obviously necessary. Deconstructive approaches, for example, are superbly productive but rarely reductive; Skopostheorie in its purest state is eminently reductive but not highly productive, and so on. This gives us a set of very practical reasons for finding virtues and faults in theories, and for teaching translation theories as such.

On the other hand, the multicomponent models seem to find little place for theory. Only Kautz (2000) explicitly mentions "translation theory and methods" as a component. Others, notably Hurtado (1999), are more concerned with distinguishing between theory and competence, ultimately in order to replace established translation theory with a list of specific and sequential "learning objectives." From this perspective, the overall tendency has been towards competence as a complex of various 
kinds of declarative knowledge and technical skills. And that is precisely the kind of knowledge that theorization is destined to challenge.

\section{Student-instructor relations}

A minimalist definition of translation competence implicitly challenges the truth models that underlie equivalence-based approaches to translation. In doing so, it also challenges the authoritarian role such models accord the teacher of translation. This means that, although teachers certainly have every right to give their own TTs and to assess the divergent TTs of individual students, the actual training of translators should not mirror the individualism of such assessment procedures. It is true that individual translators have to be able to generate and decide between alternatives, but it is rarely true that they have to do so entirely by themselves. In the training situation, the use of informants that is implicit in recourse to dictionaries and Internet resources is easily extended to the use of exchange students and academic specialists. In the professional context, these modes of interaction will then be extended to networks of contacts, clients and collaborators. Indeed, the prime impact of technology in this field is to extend the range of such networks, amplifying the productive moment and often obscuring the necessities of reduction. The ability to use and negotiate with a plurality of propositions and opinions is thus a growing part of translation competence. It should not be marginalized by individualist prejudice, the requirements of exams, or the presuppositions of research methodologies.

Emphasis on interaction as a part of translation competence should in turn influence general principles like the normality of extremely heterogeneous student groups, the need to use "authentic" or badly written texts as bases for discussion and debate, and the desirability of involving students in a wide range of professional or semi-professional activities. On these points, our minimalist approach is in fundamental accord with many of the multicomponent concepts.

\section{Solving the problem}

Let us now return to our original problem. Historical factors require us to teach our students a wide range of electronic tools, and we are not sure if these things should be admitted to our concept of translation competence. How should we now answer our students?

The easy response would perhaps be the multicomponent one: you all have to know all these things; if not, you will not find a good job, and that's that. Yet technology will always be one or two steps ahead of any multicomponential list, and the history of such concepts amounts to one of the more confused and disparate junkyards of contemporary Translation Studies. One is seriously tempted to wash one's hands of the whole affair, as indeed was Wilss's first response back in 1976.

A better answer should ensue from a minimalist definition, negotiating a few paradoxes. As we have seen, the minimalist approach is designed to promote theorization over declarative knowledge and technical skills, in keeping with a highly interactive and experiential pedagogy. And yet, on the surface, the skills associated with electronic tools are of a highly declarative and technical kind. At base, one knows how to use a given tool or one does not; one moves from simpler to more complex 
objectives; those skills rarely involve the production and selection of alternatives. As a theorizing teacher, interested in working with theorizing students, I am thus given to admit that my critical students are quite right in this case. Most of those electronic skills are not happily seen as part of translation competence; they should not be confused with the prime purpose of our teaching. They should certainly be there, in the classroom, but not enjoying pride of place.

What does this mean in practical terms? It basically suggests that we should not lose sight of our aims as translator trainers. Most of the electronic tools are simply techniques that speed up and broaden the production of alternative TTs (cf. what can be done with web searches); others are extensions that favour the authoritative elimination of alternatives (cf. the basic advantages of translation memories and glossaries of all kinds). Translators produce and select from alternatives; the various new technologies do not alter those tasks, they simply make them wider-ranging, dealing with more of the world in less time. To that extent, a minimalist view of competence should help keep us aware of the ends of our tasks, without getting lost in the means.

At the same time, a minimalist approach can sustain a critical approach to those tasks and technologies that do indeed mistake means for ends. For instance, the postmodern abundance of information makes the production of alternative TTs easy, which means that more emphasis has to be placed on the elimination of possible TTs. Students must thus be taught to mistrust websites, for instance, or at least to evaluate them with suspicion. On the other hand, the use of translation memories facilitates the unthinking repetition of previous TTs, such that what is lacking in such modes of work is the active production of hypotheses, which is clearly the side that our pedagogy should then emphasize. More important, the use of websites, memories and the rest imposes a massive mediation between the translator and the figure of the target reader. That technology invites us to forget that certain TTs are better than others because they are destined to achieve a certain purpose, in a certain time and place, for a certain end-user. They invite us to forget that our basic tasks involve communication between humans, and only then the manipulation of electronic mediation.

A minimalist concept of competence should help keep such aims clearly in sight. A multicomponent model, on the other hand, tends to accept complexity without critically distinguishing between means and ends. And that, with all due respect and comprehension, is a recipe for perdition.

\section{NOTES}

* A first version of this text was delivered to the conference Multidisciplinary Aspects of Interpretation and Translation Studies, Hankuk University of Foreign Studies, Seoul, Korea, on 21 May 2002. A later version benefited from comments by Brian Mossop. This research is part of project BFF-200203050 funded by the Ministerio de Ciencia y Tecnología, Madrid, and FEDER, to which our thanks.

1. All translations are our own.

2. This is because models initially precede empirical research, offering political virtues whose only substantial falsification is in political history. The body of empirical findings is undoubtedly growing, albeit often in a way that offers little more than self-justification. What we increasingly find is that the conditions and tools of research condition the kinds of questions we ask about translation competence. For example, since most empirical researchers are looking at individual translators working alone, they tend to ignore the more peripheral professional skills and the growing impor- 
tance of teamwork (which should extend right through to project management). One thus formulates a notion of translation competence suited to classrooms where students translate texts alone, either into the L2 (cf. Krings 1986) or from the L2 (cf. Campbell 1992, 2000). The idea of multidirectional group translation is not admitted as an object of research, simply because traditional translation classes are not designed that way. Similarly, if we have access to corpora of translational and non-translational language, we are more likely to ask about the relative variation in translators' outputs, and that will then become a component of what translational competence is all about (as has been the case in recent years). Or again, if we are going to use think-aloud protocols, our model of competence will tend to count and categorize the steps taken to solve problems (cf. Lörscher 1991). If we use Translog, we will ask about the conceptual management of time. The problem here is that, in attempting to become comprehensive in the fields where research disciplines are best established, few models successfully grasp the areas in which the most important changes are taking place (teamwork, translation memories, and the use of Internet resources). In applying inherently conservative science, they ultimately hypostatize the profession.

\section{REFERENCES}

Bachman, L. F. (1990): Fundamental Considerations in Language Testing, Oxford: Oxford University Press.

Ballard, M. (1984): “La traduction relève-t-elle d'un pédagogie?," Michel Ballard (ed.) La traduction: de la théorie à la pratique, Lille: Université de Lille III.

Bausch, K. R. (1977): “Zur Übertragbarkeit der Übersetzung als Fertigkeit auf die Übersetzung als Übungsform,” Die Neueren Sprachen 26, 517-535.

Beeby, A. (1996): Teaching Translation from Spanish to English, Ottawa: Ottawa University Press.

Beeby, A. (2000): "Choosing an Empirical-Experimental Model for Investigating Translation Competence: The PACTE Model," Maeve Olohan (ed.) Intercultural Faultlines. Research Models in Translation Studies I. Textual and Cognitive Aspects, Manchester: St Jerome, 43-55.

Bell, R. T. (1991): Translation and Translating. Theory and Practice. London and New York: Longman.

Campbell, S. (1991): “Towards a Model of Translation Competence," Meta 36-2/3, 329-343.

Campbell, S. (2000): “Choice Network Analysis in Translation Research," Maeve Olohan (ed.) Intercultural Faultines. Research Models in Translation Studies I. Textual and Cognitive Aspects, Manchester: St Jerome, 29-42.

Chomsкy, N. (1965): Aspects of the Theory of Syntax, Cambridge Mass.: MIT Press.

Fraser, J. (2000): "The Broader View: How Freelance Translators Define Translation Competence," Christina Schäffner \& Beverly Adab (eds.) Developing Translation Competence, Amsterdam \& Philadelphia: Benjamins, 51-62.

Gouadec, D. (1991): "Autrement dire... pour une redéfinition des stratégies de formation des traducteurs," Meta 36-4: 543-557.

Harris, B. (1977): “The Importance of Natural Translation,” Working Papers in Bilingualism 12, 96-114.

HARris, B. and B. Sherwood (1978): “Translating as an Innate Skill,” David Gerver \& H. Wallace Sinaiko (eds.) Language, Interpretation and Communication, New York \& London: Plenum, 155-170.

Hatim, B. and I. Mason (1997): The Translator as Communicator, London \& New York: Routledge.

Hewson, L. (1995): “Detecting Cultural Shifts: Some Notes on Translation Assessment,” Ian Mason \& Christine Pagnoulle (eds.) Cross-Words. Issues and Debates in Literary and Non-Literary Translating, Liège: University of Liège, 101-108.

Holz-Mänttäri, J. (1984): Translatorisches Handeln. Theorie und Methode, Helsinki: Academia Scientiarum Fennica.

House, J. (1986): “Acquiring Translational Competence in Interaction,” Juliane House \& Shoshana Blum-Kulka (eds.) Interlingual and Intercultural Communication: Discourse and Cognition in Translation and Second Language Acquisition Studies, Tübingen: Narr, 179-191. 
Hurtado Albir, A. (1993): “Un nuevo enfoque de la didáctica de la traducción. Metodología y diseño curricular," Les Langues étrangères dans l'Europe de l'Acte Unique, Bellaterra: ICE de la Universitat Autònoma de Barcelona.

Hurtado Albir, A. (1996): "La enseñanza de la traducción directa 'general.' Objetivos de aprendizaje y metodología," Amparo Hurtado Albir (ed.) La enseñanza de la traducción, Castelló: Publicacions de la Universitat Jaume I. 31-55.

Hurtado Albir, A. (dir.) (1999): Enseñar a traducir: metodología en la formación de traductores e intérpretes, Madrid: Edelsa.

Kautz, U. (2000): Handbuch Didaktik des Übersetzens und Dolmetschens, München: Iudicum, Goethe-Institut.

Kiraly, D. (2000): A Social Constructivist Approach to Translator Education. Empowerment from Theory to Practice, Manchester: St Jerome.

Koller, W. (1979): Einführung in die Übersetzungswissenschaft, Heidelberg: Quelle \& Meyer.

Koller, W. (1992): Einführung in die Übersetzungswissenschaft, Völlig neu bearbeitete Auflage, Heidelberg, Wiesbaden: Quelle \& Meyer.

Krings, H. P. (1986): Was in den Köpfen von Übersetzern vorgeht, Tübingen: Gunter Narr.

Lee-JahnKe, H. (1997): "Voraussetzungen für eine optimale Übersetzerausbildung heute," Eberhard Fleischmann, Wladimir Kutz, Peter A. Schmitt (eds.) Translationsdidaktik. Grundfragen der Übersetzungswissenschaft, Tübingen: Gunter Narr, 178-183.

Lörscher, W. (1991): Translation Performance, Translation Process, and Translation Strategies. A Psycholinguistic Investigation. Tübingen: Gunter Narr.

Lörscher, W. (1996): “A Psycholinguistic Analysis of Translation Processes," Meta 41-1: 26-32.

Mayoral, R. (2001): Aspectos epistemológicos de la traducción, Castelló: Publicacions de la Universitat Jaume I.

Newmark, P. (1985): “Literal Translation," Parallèles: Cahiers de l'Ecole de Traduction de Genève 7.

Nord, C. (1991): Textanalyse und Übersetzen, Heidelberg: Julius Groos.

Presas, M. (1997): "Problembestimmung und Problemlösung als Komponenten der Übersetzungskompetenz," Eberhard Fleischmann, Wladimir Kutz, Peter A. Schmitt (eds.) Translationsdidaktik. Grundfragen der Übersetzungswissenschaft, Tübingen: Gunter Narr, 587-592.

Presas, M. (1998): "Los componentes de la competencia pretraductora en el marco del diseño curricular." Isabel García Izquierdo \& Joan Verdegal (eds.) Los estudios de la traducción: un reto didáctico, Castelló: Publicacions de la Universitat Jaume I, 131-134.

Pyм, A. (1991): "A Definition of Translational Competence, Applied to the Teaching of Translation," Mladen Jovanovic (ed.) Translation: A Creative Profession: 12th World Congress of FIT. Proceedings, Belgrade: Prevodilac, 541-546.

Рyм, A. (1992): Epistemological Problems in Translation and its Teaching, Calaceite: Caminade.

Quine, W. V. O. (1975): "Reply to Harman," Donald Davidson \& J. Hintilla (eds.) Words and Objections: Essays on the Work of W. V. Quine, Revised Edition, Dordrecht \& Boston: Reidel, 267-269.

Risku, H. (1998): Translatorische Kompetenz. Kognitive Grundlegen des Übersetzens als Expertentätigkeit, Tübingen: Stauffenburg.

Saussure, F. de (1974): Cours de linguistique général, first published 1916, ed. C. Bally \& A. Sechehaye, trans. W. Baskin as Course in General Linguistics. Glasgow: Fontana Collins.

SCHÄFfner, C. and B. ADAB (2000): "Developing Translation Competence: Introduction," Christina Schäffner \& Beverly Adab (eds.) Developing Translation Competence, Amsterdam \& Philadelphia: Benjamins, vii-xvi.

Shreve, G. M. (1997): "Cognition and the Evolution of Translation Competence," Joseph H. Danks et al. (eds.) Cognitive Processes in Translation and Interpreting, Thousand Oaks, London, New Delhi: Sage.

Snell-Hornby, M. (1994) in Doina Motas, Jennifer Williams, Mary Snell-Hornby, "New Translation Departments - Challenges of the Future," Mary Snell-Hornby, Franz Pöchhacker \& Klaus Kaindl (eds.) Translation Studies, An Interdiscipline, Amsterdam \& Philadelphia: Benjamins, 431-434. 
Toury, G. (1984): “The Notion of 'Native Translator' and Translation Teaching," Wolfram Wilss \& Gisela Thome (eds.) Die Theorie des Übersetzens und ihr Aufschlusswert für dir Übersetzungsund Dolmetschdidaktik, Tübingen: Narr, 186-195.

Toury, G. (1986): “Natural Translation and the Making of a Native Translator," TextconText 1, 11 29.

Toury, G. (1995): Descriptive Translation Studies and beyond, Amsterdam \& Philadelphia: Benjamins.

Waddington, C. (2000): Estudio comparativo de diferentes métodos de evaluación de traducción general (inglés-español), Madrid: Publicaciones de la Universidad Pontificia Comillas.

WiLss, W. (1976): "Perspectives and Limitations of a Didactic Framework for the Teaching of Translation," Richard W. Brislin (ed.) Translation. Applications and Research, New York: Gardner Press, 117-137.

Wilss, W. (1982): The Science of Translation. Problems and Methods, Tübingen: Gunter Narr.

WiLss, W. (1988): Kognition und Übersetzen, Tübingen: Niemeyer.

Wilss, W. (1992): Übersetzungsfertigkeit, Annäherungen an einen komplexen übersetzungspraktischen Begriff, Tübingen: Gunter Narr.

WiLss, W. (1996): Übersetzungsunterricht. Eine Einführung, Tübingen: Gunter Narr. 